\title{
An object library approach for managing construction safety components based on BIM.
}

\author{
Jingkai Li $^{1 *}$, and Zhongyun Hua ${ }^{2}$ \\ ${ }^{1}$ Department of Real Estate \& Construction, The University of Hong Kong, Hong Kong \\ ${ }^{2}$ Department of Computer \& Information Science, University of Macau, Macau \\ *Corresponding author (jacklire@hku.hk)
}

\begin{abstract}
Purpose One of the potential solutions for designers' lack of safety expertise in design decision is utilizing IPD to allow for constructor input. But how this is to be done is often unclear because few cases from either practice or research can be found. In this study we tried to develop an IPD-method to facilitate 'safety in design' with the contractor's knowledge using an object-oriented programming (OOP) approach for design decision based on BIM. Method Our principal research method is simulation of the decision process in OOP2 in a case study. The integration of contractor's knowledge in construction safety is achieved by setting parameters for construction safety investment with contractor's input into a construction safety component library (CSCL) e.g. scaffolds, boards, barriers, etc. under the proposed IPD-framework. Results \& Discussion A prototype of CSCL using one OOP-language, C\#, is developed in Microsoft Visual Studio 2010 to Autodesk Revit 2012 with a completed construction project for demonstration. The results show that CSCL is a semiautomated tool with contractor's knowledge of construction safety for design decision. It is consistent with the theory that BIM is not only a type of software but a knowledge repository for in-depth collaboration, information sharing and knowledge re-use among all parties involved in a project. New issues and rethinks including level of detail (LoD) on company's library, IPDevaluation metrics, and BIM-development method addressing construction safety management, are also recommended in the final part.
\end{abstract}

Keywords: information technology, design decision, CSCL, BIM, IPD

\section{INTRODUCTION}

Safety is a major issue across global construction industries; loss of life through construction accidents is unacceptable. While the physical task of putting together buildings and infrastructure remains a locally embedded physical activity, it is also changed by the digital economy, which brings with it new "splintered yet connected" ways of working across global networks of design services and product supply ${ }^{18}$. It is suggested more extensive co-operation between contractor and designer is needed to improve the safety planning methods and effectiveness ${ }^{11}$.

"Safety in Design" has been stated and highlighted by many researchers ${ }^{18}$, but recent research shows that "many designers still think that safety is 'nothing to do with me' although there are a small cohort who want to engage and are having difficulty doing this because they do not fully understand what good practice looks like.". This is due to the fragmentation and document-centric nature of the traditional AEC industry ${ }^{9}$. Designers usually don't have knowledge of site safety arrangements in practice as contractors. To address these issues, Building Information Model (BIM) appears and brings about both technology and process innovation to traditional AEC industry. In this regard, the integration of construction safety information for design decision with the contractor's knowledge based on BIM is to be studied in this research. The general objectives of the research are to improve the safety performance of the construction of facilities, specifically through improving the link between design and the construction process within a proposed IPD framework.

\section{LITERATURE REVIEW \\ "Safety in Design"}

Zhou et al., 2011 gave a comprehensive review on "Construction Safety in Design" both in academic research studies and practices. Evidence indicates that "the quality and nature of design do have some impacts on construction safety ${ }^{18 "}$ However, constraints come from the traditional design-bid-build contracting arrangements, complex hierarchy of subcontracting, organizational distance, designers' liability concerns and immaturity of new forms of procurement etc. ${ }^{18}$. "Design for construction safety requires collaboration of the designer, owner, constructor, and other project parties for it to be meaningful ${ }^{18 "}$, and "there is more work to do to establish a robust evidence base to show the aspects of construction safety where design has the largest role to play ${ }^{18}$. Hence, the first Research Question is raised: How can we integrate the contractor's knowledge of construction safety into design? 


\section{Construction Safety and BIM}

$\mathrm{Ku}$ and Mills, 2010 reviewed and summarized the current Design-for-Safety Tools, and classified them in four types: Hazard recognition (Checklists, Computer software (ToolBox)), Risk assessment (Risk mitigation forms Computer software (ToolSHeD)), Procedure (Review tools (CHAIR)), and Visualization (3D/4D CAD Virtual construction) ${ }^{12}$. It was then suggested that "BIM offers opportunities to assist design teams to automate hazard recognition and design optimization processes"12. Developments in BIM and Computer Tools for Safety were then categorized into two areas of computational support: design review and simulation. Research Suggestions for future BIM Tools for Safety were concluded as 1) 4D model integration with hazards database; 2) Development of custom rules for safety considerations; 3) Level of Details (LoD) for construction equipment and workers; and 4) Integrated agent-based modeling for design changes, delays etc. ${ }^{12}$. But these were all function/technology driven approach/strategy, and lack of consideration on collaboration of multi-parties in a project.

\section{BIM and Object Library}

BIM platforms have various libraries of predefined objects that can be imported for use. These are helpful by eliminating the need to define them yourself. And in general, the more predefined objects, the more helpful". "Currently, there is little effort to standardize the structure of object information beyond geometry $6 . "$ Furthermore, if the BIM tool is customized for architectural practice, even more efficiency gains can be achieved towards a better design practice" ${ }^{6}$. And "One crucial precondition regarding BIM-based site planning in real-life projects would be that planner has a predefined set of $3 D$ objects over most often used site equipment. This would facilitate and accelerate site planning clearly ${ }^{6 "}$ But what kind of safety components are to be composed in the library and how to integrate the Construction Safety Component Library for design decision? These also serve as the second Research Question.

\section{IPD}

Implementing BIM effectively does not only require learning new software applications, but also how to reinvent the workflow, how to train staff and assign responsibilities, and changing the way of modeling the construction ${ }^{3}$. At the mention of BIM, the topic on Integrated Project Delivery (IPD), which is a comprehensive procurement method, is followed among researchers and practitioners. BIM is not only a type of software but a human activity that ultimately involves broad process changes in AEC industry ${ }^{6}$. Generally, "IPD is a deeply collaborative process that uses best available technology, but goes beyond merely the application of digital tools, such as Building Information Modeling" "IPD seeks to "improve project outcomes through a collaborative approach of aligning the incentives and goals of the project team through shared risk and reward, early involvement of all parties, and a multiparty agreement ${ }^{10 \text { " }}$ And one of the potential solutions for designers' lack of safety expertise is utilizing IPD to allow for constructor input ${ }^{17}$. But "how" remains confusing to us because only a few cases in both practices and research studies can be found. More specific research studies should be carried out in this area to enrich the theory of IPD and more implementation should be conducted among industries for best practices.

\section{RESEARCH METHODOLOGY}

\section{Construction Safety Component Library (CSCL)}

The Construction Safety Component Library (CSCL) in this paper is defined as an Object Library consisting of construction safety site equipment including General Equipment e.g. Metal Fencing, Protective Net, Catch Fan etc. and Personal Protective Equipment e.g. Helmet, Reflective Vest, Safety Boot etc. with generated performance indicator for design decision. The Object here refers to the Construction Safety Component or equipment.

\section{Construction Safety Investment}

The specific construction safety information or performance indicator is a prerequisite for the model established in this study. Requirements and criteria should be met as: 1) As a variable dependent on both design decision and the contractor's input; 2) easy to be captured to represent the contractor's knowledge, technique, experiences etc. and reflect the contractor's competence in safety performance; 3) easy to be generated through the model and the result is obvious enough to evaluate the design decision. Slaughter, 2003 proposed a Dynamic Process Simulation Model of Construction Activities, which could generate the impact of design alternatives on construction cost/schedule/safety. The safety in the model was defined as the index of the exposure of workers to dangerous conditions calculated from the task duration matched to the OHSA-identified causes of worker injury ${ }^{15}$. But recent research showed that the occupational accidents suffered by construction workers at different hours of the day are different ${ }^{14}$, thus the task duration may not reflect the situation in this regard. The safety performance generated by model was based on the consequence and loss by injuries but not the prevention measures like investment on safety equipment and training etc. which should form the strategy of "Prevention through Design". Gambatese et al., 2005 pointed "designing for safety has resulted in positive impacts to construction $\cos t^{8}$ ", and "furthermore, if the entire life cycle of a project and sustained purchasing of construction 
services are considered, the potential benefits are expanded as design changes which initially may be costly become long-term benefits as a result of lower construction costs and improved safety during operation and maintenance ${ }^{8}$." Compared with the requirements/criteria above, the Construction Safety Investment among Construction Schedule Delay and Construction Plan Change ${ }^{12}$ etc. is to be regarded as the indicator and the specified construction safety information for integration.

Sun, 2010 reviewed and classified the Components of Safety Investment into two main categories: physical and cultural. While physical inputs include another two main categories: on-site safety management and designing for safety. On the other hand, cultural input refers to the cultivation of safety culture in both project and organizational level ${ }^{16}$. The simplified Construction Safety Investment model for design decision in this study is:

$$
C S I_{i}=\left(\sum G E_{j i}+\sum P P E_{j i}\right) \cdot\left(1+\alpha_{k}\right)
$$

Where,

$\mathrm{CSI}_{i}$ - Construction Safety Investment based on Design Decision $i$.

$G E_{j i}$ - Cost of General Equipment $j$ based on Design Decision $i$.

$P P E_{j i}$ - Cost of Personal Protective Equipment $j$ based on Design Decision $i$.

$\alpha_{k}$ - Safety Cultural Adjustment Coefficient of Con-

tractor $k$, which also needs to be refined by researchers and practitioners.

\section{Development of the Prototype}

The prototype is developed in C\# in Microsoft Visual Studio 2010 IDE based on Microsoft .NET Framework. Thus C\#.NET is used to develop a prototype of the Object Library for CSCL. ADO.NET (ActiveX Data Objects for .NET) is used to access the program to the Microsoft SQL Server database, which stores the contractor's input of the quantity and price information in the CSCL. The link to the database allows for the track of the modification of CSCL for record and documentation, and retrieval of contractor's knowledge. ADO.NET provides an easy, efficient way to access database. It is a set of computer software components that programmers can use to access data and data services. And it is a part of the base class libraries that is included within Microsoft .NET Framework. ADO.NET is commonly used by programmers to access and modify data stored in database systems with many pre-defined dataset objects. The system diagram of the prototype is shown in Fig.1.

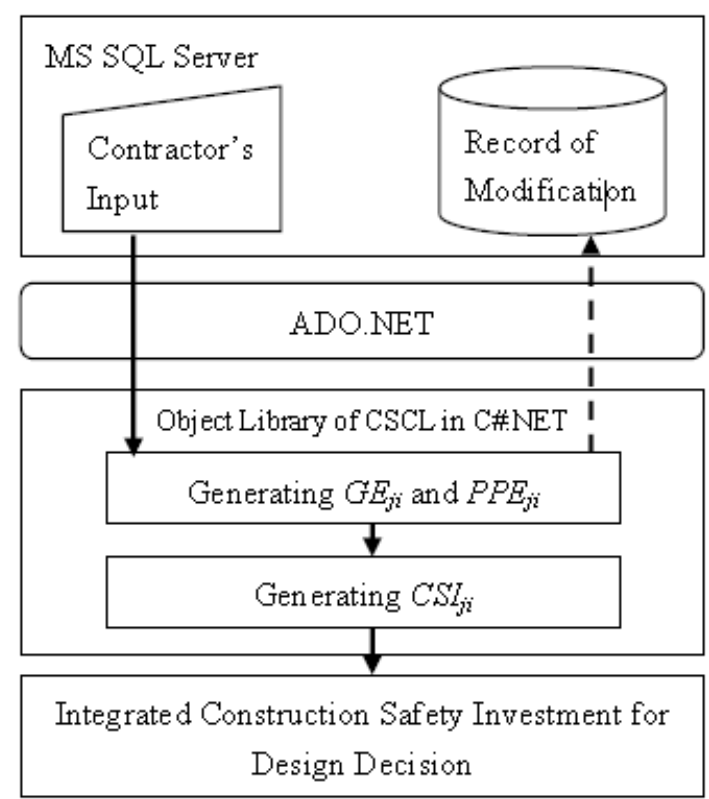

Fig.1. Diagram of the System and Information Flow of the Prototype

\section{Results}

To test the applicability of the model, which refers to the involvement of the contractor for design decision and knowledge retrieval in the process, a real construction project with the contractor was selected for demonstration. The façade of a building involves more design work by the contractor compared to other parts, and the contractor would have more experience and knowledge in design and construction/fabrication of the façade. The selection criteria for the project were then set to a building with typical and complete façade with the contractor's Safety Standards/Instructions/Requirements for the project's façade engineering. The model is configured to use the detailed design attributes for a specific project as input of the design alternative.

A completed Construction Project A, including shop drawings, construction method, plan and schedule with Contractor A in Hong Kong was selected according the criteria. Although it is a completed one, it does not affect testing the applicability of the model. Project $A$ is an office building of $69 \mathrm{~F}$ to the main roof, with a footprint of 51.6 by $51.6 \mathrm{~m}$, with the floor-tofloor height of $4 \mathrm{~m}$, all enveloped with glass curtain walls in the exterior enclosure system. The building components: glass curtain walls (only one facet out of four for simplification) with its attributes represents the design decision, and the design alternative would be the length, height, and density etc. of the glass curtain wall panels in this facet; the Construction Safety Components are selected according to the Chapter of Working at Height and Chapter of Personal Protective Equipment in the Book of Safety Standards and HS\&E Concerns for Project A provided by Contractor A, namely Metal Fencing, Protec- 
tive Net, Catch Fan and Gondola as the general equipment, and Helmet, Reflective Vest, Safety Boot etc. as the Personal Protective Equipment, which represent the contractor's knowledge on Construction Safety Investment with the input value to their attributes. The whole project was then established in Autodesk Revit Architecture 2012 as a BIM platform with good quality in visual presentation and information inquiry in 3D view. The required quantity and price of each Construction Safety Component for the original Design Decision were then got from Contractor A according to the project's construction method, plan and schedule, shown in the following tables.

Table 1. Attributes of Construction Safety Components (General Equipment) with quantity and price information

\begin{tabular}{|c|c|c|c|}
\hline & Gondola & $\begin{array}{c}\text { Catch Fan } \\
\text { (Type 1) }\end{array}$ & $\begin{array}{l}\text { Catch Fan } \\
\text { (Type 2) }\end{array}$ \\
\hline type & $5.0 \mathrm{~m} \times 0.5 \mathrm{~m} \times$ & $31.4 \mathrm{~m} \times$ & $33.6 \mathrm{~m} \times$ \\
\hline (Lengthx & $0.9 \mathrm{~m}$ & & \\
\hline Widthx & & & \\
\hline Height) & & & \\
\hline quantity & 3 & 1 & 1 \\
\hline price & $\begin{array}{l}\mathrm{HK} \$ 200000 \\
*\end{array}$ & $\begin{array}{l}\mathrm{HK} \$ 23500 \\
\star\end{array}$ & $\begin{array}{l}\mathrm{HK} \$ 25200 \\
\star\end{array}$ \\
\hline $\begin{array}{l}\text { scope of } \\
\text { services }\end{array}$ & G/F to Roof & $\begin{array}{l}\text { 69/F to } \\
\text { Roof }\end{array}$ & $\mathrm{G} / \mathrm{F}$ to $69 / \mathrm{F}$ \\
\hline $\begin{array}{l}\text { safe work- } \\
\text { ing load and } \\
\text { max. no. of } \\
\text { persons }\end{array}$ & $\begin{array}{l}\text { 200kg/each } \\
\& \text { 2/each }\end{array}$ & \multicolumn{2}{|c|}{$\mathrm{N} / \mathrm{A}$} \\
\hline $\begin{array}{l}\text { safety har- } \\
\text { ness with } \\
\text { independ- } \\
\text { ent lifeline } \\
\text { and fall } \\
\text { arrestor }\end{array}$ & 6 & \multicolumn{2}{|c|}{ N/A } \\
\hline $\begin{array}{l}\text { price of } \\
\text { safety har- } \\
\text { ness }\end{array}$ & $\mathrm{HK} \$ 50 * *$ & \multicolumn{2}{|c|}{$\mathrm{N} / \mathrm{A}$} \\
\hline \multirow[t]{3}{*}{ remarks } & $\begin{array}{l}{ }^{*}(\text { provided } \\
\text { by the sub- } \\
\text { contractor, } \\
\text { operation } \\
\text { cost around } \\
\$ 2,000 / \text { day) }\end{array}$ & \multirow{3}{*}{\multicolumn{2}{|c|}{$\begin{array}{l}*(\$ 250 / \mathrm{m} 2 / 10 \text { months by } \\
\text { rental }) \times 10 \text { months }\end{array}$}} \\
\hline & $\times 100$ days & & \\
\hline & $* \star \$ 50 /$ unit & & \\
\hline $\begin{array}{l}\text { new attrib- } \\
\text { ute }\end{array}$ & \multicolumn{3}{|c|}{$N / A$} \\
\hline
\end{tabular}

\section{Continue}

\begin{tabular}{|l|c|c|c|c|}
\hline & $\begin{array}{c}\text { Protective } \\
\text { Net (Type } \\
\text { 1) }\end{array}$ & $\begin{array}{c}\text { Protec- } \\
\text { tive Net } \\
\text { (Type 2) }\end{array}$ & $\begin{array}{c}\text { Metal } \\
\text { Fencing } \\
\text { (Type 1) }\end{array}$ & $\begin{array}{c}\text { Metal } \\
\text { Fencing } \\
\text { (Type 2) }\end{array}$ \\
\hline $\begin{array}{l}\text { type } \\
\text { (Lengt } \\
\mathrm{h} \times\end{array}$ & $\begin{array}{c}31.4 \mathrm{~m} \times \\
\text { Height) }\end{array}$ & $\begin{array}{c}33.6 \mathrm{~m} \times \\
3.1 \mathrm{~m}\end{array}$ & $\begin{array}{c}31.4 \mathrm{~m} \times \\
1.0 \mathrm{~m}\end{array}$ & $\begin{array}{c}33.6 \mathrm{~m} \times \\
1.0 \mathrm{~m}\end{array}$ \\
\hline $\begin{array}{l}\text { quanti- } \\
\text { ty }\end{array}$ & 1 & 69 & 1 & 69 \\
\hline price & $\mathrm{HK} \$ 1004$ & $\mathrm{HK} \$ 520$ & $\mathrm{HK} \$ 376$ & $\mathrm{HK} \$ 403$ \\
\hline
\end{tabular}

\begin{tabular}{|c|c|c|c|c|}
\hline & 8* & $8^{*}$ & $8^{*}$ & $2 *$ \\
\hline $\begin{array}{l}\text { scope } \\
\text { of } \\
\text { ser- } \\
\text { vices }\end{array}$ & $\begin{array}{l}\text { 69/F to } \\
\text { Roof }\end{array}$ & $\begin{array}{l}\mathrm{G} / \mathrm{F} \text { to } \\
69 / \mathrm{F}\end{array}$ & $\begin{array}{l}\text { 69/F to } \\
\text { Roof }\end{array}$ & $\begin{array}{l}\text { G/F to } \\
69 / F\end{array}$ \\
\hline $\begin{array}{l}\text { re- } \\
\text { marks }\end{array}$ & $\begin{array}{l}{ }^{\star}(\$ 50 / \mathrm{m} 2 \\
\text { by rental })\end{array}$ & $\begin{array}{l}\text { nonths } \\
\text { months }\end{array}$ & $\begin{array}{l}*(\$ 120 / \mathrm{m} \\
\text { months } \\
\text { al }) \times 10 \mathrm{~m}\end{array}$ & $\begin{array}{l}0 \\
\text { ent- } \\
\text { hs }\end{array}$ \\
\hline $\begin{array}{l}\text { new } \\
\text { attrib- } \\
\text { ute }\end{array}$ & \multicolumn{4}{|c|}{ N/A } \\
\hline
\end{tabular}

Table 2. Attributes of Construction Safety Components (Personal Protective Equipment) with quantity and price information

\begin{tabular}{|l|c|c|}
\hline Personal Protective Equipment & quantity & price \\
\hline helmet & 6 & $\$ 20 /$ unit \\
\hline reflective vest & 6 & $\$ 20 /$ unit \\
\hline safety boot & 6 & $\$ 250 /$ unit \\
\hline safety harness & 6 & $\$ 50 /$ unit \\
\hline cotton glove & N/A & $\$ 5 /$ unit \\
\hline leather glove & 6 & $\$ 30 /$ unit \\
\hline ear defender/plug & N/A & $\$ 2 /$ unit \\
\hline $\begin{array}{l}\text { safety spectacles (general pur- } \\
\text { pose) }\end{array}$ & N/A & \$90/unit \\
\hline $\begin{array}{l}\text { safety goggle (dealing with } \\
\text { chemicals) }\end{array}$ & N/A & \$120/unit \\
\hline dust mask & & \\
\hline cartridge respirator & N/A & \$2/unit \\
\hline new attribute & N/A & \\
\hline
\end{tabular}

The design decision would be an iterative process with the early involvement of the contractor in this model, the generated Construction Safety Investment would be the determinant for the design decision, and if the result doesn't meet the criteria of the Investment, the building components (the glass curtain walls in the one facet) would be redesigned and the process would be run again. The model also enables the track of the modification of Construction Safety Components in the database for record and documentation. The value of $\alpha_{k}$ is assumed to be 0.32 to run the program. The generated results $(\mathrm{HK} \$ 1,719,427)$ within the iterative process and track of modification in the database are illustrated in the figures below. 


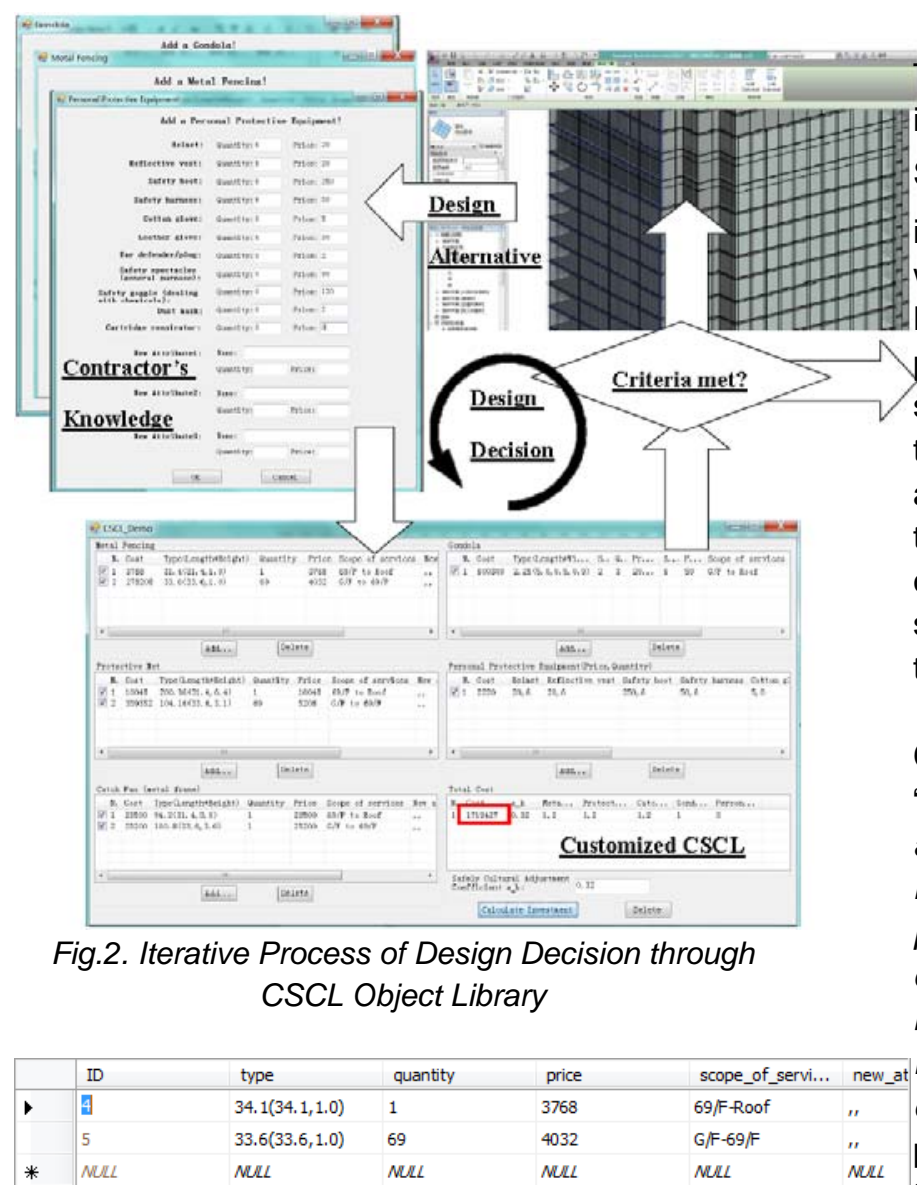

Fig.3. Track of Modification in MS SQL Server (an example of a new Metal Fencing record created and saved in the database)

\section{FINDINGS}

The applicability of the proposed model with regard to the involvement of the contractor for design decision and knowledge retrieval in the process was tested by a real construction project in Hong Kong. The required data can be obtained from the contractor, and the generated result as a variable dependent on both design decision and the contractor's input is obvious enough to evaluate the design decision. The Construction Safety Components are selected as customized ones according to the documents provided by the contractor, and can represent the contractor's knowledge, technique, experiences etc. to reflect the contractor's competence in safety performance. CSCL is a semi-automated tool with contractor's knowledge of construction safety for design decision within the proposed IPD framework. However, according to the contractor's view, it is difficult to build up a database for CSCL that can apply to every design, as building design most of time is unique except public housing, and the market may not willing to spend money to build up the database to suit different kind of building design in the context of Hong Kong. The contractor still believes it can be treated as a stimulation to let people consider safety components at design stage.
The prerequisite to implement the model in this study is the Input based on the contractor's knowledge (e.g. Safety Cultural Adjustment Coefficient $\alpha_{k}$ proposed in the model). More researches should be carried out with leading contractors to establish their Safety Libraries for knowledge management in their safety performance. And more evaluations of the model should be conducted in terms of different building types (commercial, residential, public, industrial etc.) and ongoing projects, the decision on design alternatives should be classified in different phases: conceptual design or detailed design etc., the impacts should be collected on safety decisions, on-site safety performance and barriers to its implementation.

\section{Conclusions}

"One of the most fundamental advantages that IPD affords is the ability for all parties to be present and involved with a project from the earliest design phase. Early collaboration, under the right conditions, can directly address the problem of fragmentation between design and construction professionals that results in inefficient work practices and costly changes late in the construction phase ${ }^{10 "}$ And one of the potential solutions for designers' lack of safety expertise is utilizing IPD to allow for constructor input ${ }^{17}$. But "how" remains confusing to us because only a few cases in both practices and research studies can be found. The model established through Input from the contractor using Object Library in this research is an example for illustration. And it is a method for the early involvement of contractors with their knowledge for design decision from the perspective of construction safety. The general objectives of the research are to improve the safety performance of the construction of facilities, specifically through improving the link between design and the construction process within a proposed IPD framework.

The potential link of design and construction is use of the model by designers and contractors to analyze design alternatives to improve their planning and control capabilities in safety performance. The company could use the model with customized safety components for a specific project to understand the nature of their activities and the impact that design alternatives would have on their investments in construction safety. These analyses could provide a critical feedback system for design and construction organizations to learn across projects to improve their internal competencies in safety performance. It could also provide a means to assess and improve the designs, components, systems, and process of construction projects, as well as to improve the efficiency of the design and construction processes. 
The functionality and quality of the Library in BIM platforms were described as "Library objects will need to be accessed and integrated into projects using the standard nomenclature defined within that BIM platform for proper interpretation. Full integration includes object classification, naming conventions, attribute structure etc. ${ }^{6 .}$ And a well-designed library management system should include "the ability to create catalogs of objects in a library (Library views) for specific projects or building types, and functionality for resolving discrepancies between object names and property sets across catalogs of objects" ${ }^{6}$ "The future research directions could be identified as Level of Details (LoD), Meta-data, Ontology and Taxonomy of CSCL for generalization, and the IFCcompliant description for interoperability and integration.

\section{References}

1. Ahn, S, Park, M, Lee, H and Yang, Y., "Objectoriented modeling of construction operations for schedule-cost integrated planning, based on BIM", Proceedings of the International Conference on Computing in Civil and Building Engineering (C) Nottingham University Press, 2010.

2. AIA California Council, "Integrated Project Delivery - A Working Definition", McGraw-Hill Construction, 2007.

3. Arayici, Y., Coates, P., Koskela, L. and Kagioglou, M., "BIM adoption and implementation for architectural practices", Structural Survey, Vol. 29 No. 1, pp. 7-25, 2011.

4. Autodesk Inc., "Autodesk BIM Deployment Plan: A Practical Framework for Implementing BIM", 2010.

5. Brace, C., Gibb, A., Pendlebury, M. and Bust, P., "Health and safety in the construction industry: Underlying causes of construction fatal accidents - external research", Secretary of State for Work and Pensions, Inquiry into the underlying causes of construction fatal accidents, Loughborough University, Loughborough, http://www.hse.gov.uk/construction/resources/pha se2ext.pdf, 2009.

6. Eastman, C., Teicholz, P., Sacks, R. and Liston, K., "BIM Handbook: A Guide to Building Information Modelling for Owners, Managers, Designers, Engineers, and Contractors", Second Edition, John Wiley \& Sons, 2011.

7. Gambatese, J.A., "Rapporteur's Report: Research Issues in Prevention through Design", Journal of Safety Research 39, 153-156, 2008.

8. Gambatese, J.A., Behm, M and Hinze, J.W., "Viability of Designing for Construction Worker Safety", Journal of Construction Engineering and Management, Vol. 131, No. 9, 2005.

9. Isikdag, U. and Underwood, J., "Two design patterns for facilitating Building information Modelbased synchronous collaboration", Automation in Construction 19, 544-553, 2010.

10. Kent, D.C. and Becerik-Gerber, B., "Understand- ing Construction Industry Experience and Attitudes toward Integrated Project Delivery", Journal of Construction Engineering and Management, Vol. 136, No. 8, 2010.

11. Kiviniemi, M., Sulankivi, K., Kähkönen, K., Mäkelä, T. \& Merivirta, M., "BIM-based Safety Management and Communication for Building Construction", Espoo, VTT Tiedotteita - Research Notes 2597, 2011.

12. Ku, K. and Mills, T., "Research needs for Building Information Modeling for Construction Safety", http://ascpro.ascweb.org/chair/paper/CPGT15900 2010.pdf, 2010.

13. Long, N., Fleming, K. and Brackney, L., "An Object-Oriented Database for Managing Building Modeling Components and Metadata", Proceedings of Building Simulation 2011: 12th Conference of International Building Performance Simulation Association, Sydney, 14-16 November, 2011.

14. López, M.A.C., Fontaneda, I., Alcántara, O.J.G. and Ritzel, D.O., "The special severity of occupational accidents in the afternoon: "The lunch effect"', Accident Analysis and Prevention 43, 11041116, 2011.

15. Slaughter, S., "The link between design and process: Dynamic process simulation models of construction activities", 4D CAD and visualization in construction: developments and applications, Gainesville, 145-164, 2005.

16. Sun, C., "An Analysis of Return on Investment on Safety Management Program in Construction Projects", M.Phil. Dissertation, The University of New South Wales, 2010.

17. Toole, T.M. and Gambatese, J.A., "Safety in Design and Construction: A Lifecycle Approach Design for Construction Safety in the U.S." http://www.designforconstructionsafety.org/Docum ents/Design\%20for\%20Construction\%20Safety\%2 Oin\%20the\%20us\%20-

\%20Toole\%20and\%20Gambatese\%202011\%20fi nal.pptx, 2012.

18. Zhou, W, Whyte, J. and Sacks, R., "Construction safety and digital design: A review", Automation in Construction 22 102-111, 2012. 